\title{
ROLA DENDROFLORY WE WZBOGACANIU WALORÓW KRAJOZNAWCZYCH OBSZARÓW ZURBANIZOWANYCH
}

\section{Wstęp}

Drzewa w krajoznawstwie postrzegane są zwłaszcza przez pryzmat pomników przyrody. Jest to grupa najczęściej eksponowanych przez gminy okazów, a głównym kryterium uznania ich za pomniki przyrody jest obwód mierzony na wysokości $130 \mathrm{~cm}$. Pozostałe kryteria często stanowią tylko dodatkowe uzasadnienie tej decyzji. Na terenach zurbanizowanych jednym z ważniejszych wskazań do objęcia ochroną drzew jest ich wartość historyczna, której poświęca się mało uwagi, traktując ją powierzchownie i często dość ogólnikowo. Pietrzak-Zawadka (2016), kategoryzując pomniki przyrody, nie podjęła próby ich klasyfikacji pod kątem wartości historycznej i ograniczyła się jedynie do informacji o występowaniu drzew w legendach i wykorzystywaniu ich w turystyce. Natomiast Grzywacz (2011) odniósł się jedynie do ogólnych przesłanek wynikających z wartości kulturowej drzew. Dla Zarzyńskiego i Grzywacza (2019) wartość historyczna drzew jest efektem ich powiązania z postaciami i faktami historycznymi. Bardziej szczegółowo do oceny wartości historycznej podchodzi Kasprzak (2011). Orłowski i Nowak (2007) oraz Affek-Starczewska, Starczewski, Pawlonka i Skrzyczyńska (2014) stwierdzili, że w Polsce najwięcej drzew o wymiarach pomnikowych oraz będących pomnikami przyrody znajduje się w parkach i alejach, co jest związane $\mathrm{z}$ bezpośrednią działalnością człowieka. Szczególnie dużą wartość mają aleje jako elementy historycznych układów przestrzennych (Fortuna-Antoszkiewicz, Łukaszkiewicz, 2018). Sobolewski, Ostrowska-Dudys i Janas (2017) wykazali, że w Bolkowie najcenniejsze drzewa związane są z zielenią towarzysząca, pełniącą współcześnie odmienne funkcje niż kiedyś. W Polsce najczęściej 
ustanawianymi pomnikami przyrody są drzewa z gatunków rodzimych, np.: buk, dąb, lipa oraz jesion, a z gatunków obcych - kasztanowiec i platan (Pietrzak-Zawadka, 2015). W rozważaniach na temat pomników przyrody pomija się informacje dotyczące unikatowości cennych gatunków i odmian. Przykładem może być praca Szczepańskiego, Wrońskiej-Pilarek i Janyszek (2018), poświęcona dendroflorze parku w Buczku Małym (województwo wielkopolskie). Autorzy, wskazując drzewa godne ochrony, kierowali się wyłącznie kryterium obwodu. Pominęli takie okazy, jak klon pospolity 'Lorbergii' (Acer platanoides L. 'Lorbergii') czy buk pospolity 'Laciniata' (Fagus sylvatica L. 'Laciniata'), których ochrona $\mathrm{z}$ uwagi na niepowtarzalność i wartość historyczną jest priorytetowa.

\section{Materiały i dowody}

W pracy przedstawiono zbiór opracowań dotyczących dendroflory Dolnego Śląska jako studium licznych przypadków, których opisanie pomoże uporządkować i przybliżyć wiedzę na temat walorów krajoznawczych drzew na terenach obszarów zurbanizowanych Dolnego Śląska. W artykule wykorzystano wybrane informacje z lat 2016-2019, pochodzące z projektów realizowanych przez organizacje, których celem jest upowszechnianie wiedzy o cennych drzewach regionu:

- edukacyjna ścieżka dendrologiczna „Drzewa-dziedzictwo przyrodniczo-kulturowe Bolkowa" - projekt realizowany przez Towarzystwo Miłośników Bolkowa na terenie miasta Bolkowa;

- „Drzewa Dobrej Widawy” - projekt realizowany przez Fundację Aquila na terenie gmin: Czernica, Długołęka, Jelcz-Laskowice;

- „Park 51" - projekt realizowany przez Fundację Inicjatywa B na terenie parku Miejskiego w Żarowie.

Dodatkowo na podstawie informacji na temat form ochrony przyrody z 2015 i 2019 r. (pozyskanych od Regionalnej Dyrekcji Ochrony Środowiska we Wrocławiu) opracowano zestawienie tabelaryczne okazów rzadkich gatunków i odmian drzew, których tylko pojedyncze egzemplarze objęto ochroną pomnikową w województwie dolnośląskim. Ponadto pracę uzupełniono o informacje niepublikowane wcześniej przez autora. Dla wybranych przykładów dokonano zestawień fotografii archiwalnych i współczesnych.

Sobolewski, Sabura-Mielnik i Szopińska (2018) podjęli próbę uszczegółowienia powodów ochrony drzew. Do tych motywów należą m.in.: rola w folklorze, wierzeniach oraz tradycjach lokalnych, historyczne odmiany 
drzew parkowych/ozdobnych, powiązania z obiektami i założeniami historycznymi, unikatowość, występowanie w stanowiskach naturalnych, wartość ekologiczna i biocenotyczna. Uściślając, wartość drzew - poza szeroko pojętym i niepodważalnym znaczeniem przyrodniczym - na terenach zurbanizowanych należy rozpatrywać w aspektach:

1) unikatowości w skali regionu:

- największe i najwyższe (obwód, wysokość);

- najstarsze (wiek);

- najrzadziej występujące (gatunki bądź odmiany);

- wynikająca z cech osobniczych, np. pokroju;

2) znaczenia historycznego:

- drzewa udokumentowane na fotografiach archiwalnych;

- drzewa powiązane z założeniami i obiektami historycznymi;

- drzewa relikty niezachowanych założeń i układów kompozycyjnych;

- drzewa wykorzystywane w doborach gatunkowych, charakterystyczne dla danego miasta, wsi bądź regionu;

- drzewa będące starymi odmianami historycznymi;

3) walorów estetycznych:

- drzewa o wartości ozdobnej, wynikającej z cech gatunkowych;

- drzewa o wartości krajobrazowej - powiązane w czasie i przestrzeni $\mathrm{z}$ innymi elementami krajobrazu.

\section{Wyniki i dyskusja}

Najczęściej wyjątkowość drzewa wiąże się z jego obwodem i wiekiem, a ponadto $\mathrm{z}$ nietypowymi cechami osobniczymi, jak w przypadku form pokrojowych sosen pospolitych (Pinus sylvestris L.), do których należy tzw. sosna na szczudłach, rosnąca w Wełczu (gmina Busko-Zdrój) (Grzywacz, 2011), czy sosna Ośmiornica z gminy Brody (Markulak, 2014). Sporadycznie rozpatruje się kryterium unikatowości w odniesieniu do rzadko spotykanego gatunku bądź nietypowej odmiany, zwłaszcza na terenach zieleni historycznej. Mimo uznawania obwodu za najważniejsze kryterium, wbrew powszechnemu przekonaniu nie zawsze będzie on jednoznacznie wskazywał na wiek drzewa. Warto przytoczyć przykład sosny pospolitej rosnącej na skałkach Karczmarz przy ul. Jedności Narodowej w Szklarskiej Porębie. Drzewo to zostało uwiecznione na fotografii archiwalnej z 1911 r. (fot. 1). Na to, że obecnie mamy do czynienia z tym samym okazem, wskazuje przede wszystkim krzywizna jego pnia (fot. 2). Tym samym wiek omawianej sosny pospolitej wynosi ponad 110 lat. 
Opierając się na klasyfikacji Pietrzak-Zawadki (2016), ową sosnę można uznać - w tym przypadku niesłusznie - za drzewo o małej wartości. Potwierdzony dokumentacją archiwalną sędziwy wiek drzewa w połączeniu z bardzo małym obwodem pnia świadczy o jego bezprecedensowej niepowtarzalności.

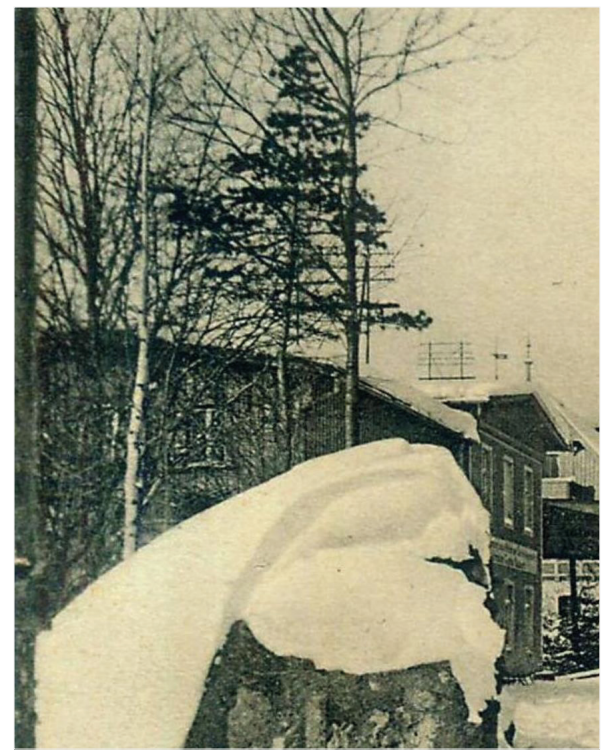

Fotografia 1. Sosna pospolita rosnąca na skałkach Karczmarz w Szklarskiej Porębie przy ul. Jedności Narodowej-1911 r. Źródło: Polska-org.pl (2019)

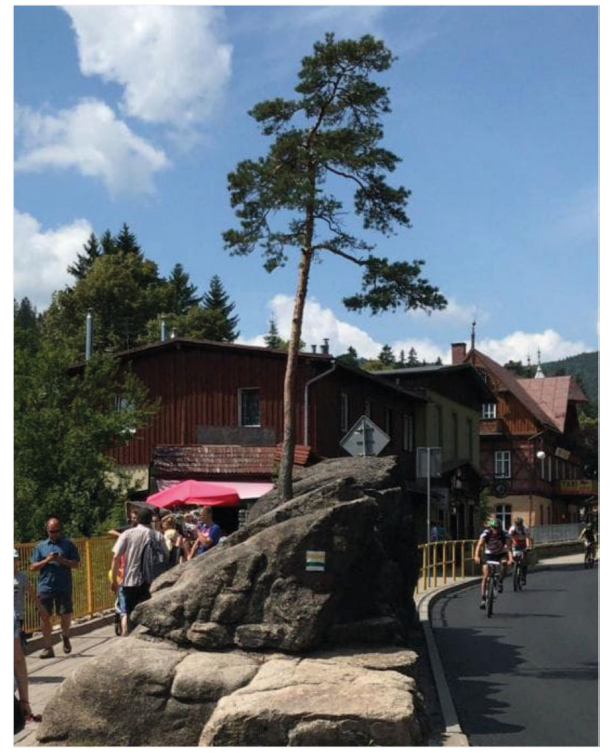

Fotografia 2. Sosna pospolita rosnąca na skałkach Karczmarz w Szklarskiej Porębie przy ul. Jedności Narodowej- 2019 r. Źródło: J. Lewandowska

W przypadku drzew obcego pochodzenia ich wiek często nie przekracza 200 lat, co zbiega się z okresem tworzenia parków i innych terenów zieleni. Dlatego też wiek pojedynczych drzew należy wiązać z datą utworzenia poszczególnych założeń parkowo-ogrodowych i z przeobrażeniami kompozycji, którym podlegały wraz z upływem czasu.

Na Dolnym Śląsku w kilkunastu przypadkach możemy spotkać wyłącznie pojedyncze okazy poszczególnych gatunków i odmian drzew, które zostały uznane za pomniki przyrody. Warto tu wymienić m.in. ambrowiec amerykański (Liquidambar styraciflua L.) czy dąb szypułkowy 'Pectinata' (Quercus robur L. 'Pectinata') (tab. 1). Spośród unikatowych taksonów objętych ochroną największy obwód ma dąb wielkoowocowy (Quercus macrocarpa Michx.). W dniu ustanowienia drzewa pomnikiem przyrody 
jego obwód wynosił $410 \mathrm{~cm}$. Objęty ochroną pomnikową został ponadto jeden dąb kaukaski (Quercus macranthera Fisch. \& C.A. Mey. ex Hohen.), rosnący w Pielgrzymce. Na Dolnym Śląsku stare okazy tego gatunku notowane były również w Karpnikach (Malicki, 2007), Ziębicach (Gębska, Jakubska, 2007) i w parku Szczytnickim we Wrocławiu (Szopińska, Reda, 2003).

Tabela 1. Okazy rzadkich gatunków drzew, których wyłącznie pojedyncze egzemplarze objęte są ochroną pomnikową na Dolnym Śląsku (stan na 29 kwietnia 2019 r.)

\begin{tabular}{|c|c|c|c|}
\hline $\begin{array}{l}\text { Nazwa gatunkowa } \\
\text { polska i łacińska }\end{array}$ & $\begin{array}{l}\text { Obwód } \\
{[\mathrm{cm}]}\end{array}$ & $\begin{array}{c}\text { Miejscowość } \\
\text { (gmina) }\end{array}$ & Lokalizacja \\
\hline $\begin{array}{l}\text { Ambrowiec amerykański } \\
\text { Liquidambar styraciflua L. }\end{array}$ & 145 & $\begin{array}{l}\text { Jedlina-Zdrój } \\
\text { (Jedlina-Zdrój) }\end{array}$ & $\begin{array}{l}\text { ul. Cmentarna, } \\
\text { przy posesji }\end{array}$ \\
\hline $\begin{array}{c}\text { Dąb szypułkowy } \\
\text { 'Pectinata' } \\
\text { Quercus robur L.'Pectinata' }\end{array}$ & 279 & $\begin{array}{l}\text { Jelenia Góra } \\
\text { (Miasto Jelenia } \\
\text { Góra) }\end{array}$ & $\begin{array}{l}\text { Jelenia Góra - Sobieszów, } \\
\text { ul. T. Chałubińskiego } 15\end{array}$ \\
\hline $\begin{array}{c}\text { Dąb wielkoowocowy } \\
\text { Quercus macrocarpa } \\
\text { Michx. }\end{array}$ & 410 & $\begin{array}{l}\text { Bolesławiec } \\
\text { (Bolesławiec) }\end{array}$ & $\begin{array}{c}\text { ul. Kwiatowa } 2 \\
\text { - przy budynku } \\
\text { Zakładu Przemysłu } \\
\text { Dziewiarskiego Concordia }\end{array}$ \\
\hline $\begin{array}{c}\text { Dąb kaukaski } \\
\text { Quercus macranthera } \\
\text { Fisch. \& C.A. Mey. } \\
\text { ex Hohen. }\end{array}$ & 240 & $\begin{array}{l}\text { Pielgrzymka } \\
\text { (Pielgrzymka) }\end{array}$ & park \\
\hline $\begin{array}{c}\text { Lipa szerokolistna } \\
\text { 'Laciniata' } \\
\text { Tilia platyphyllos Scop. } \\
\text { 'Laciniata' }\end{array}$ & 123 & $\begin{array}{l}\text { Szczawno-Zdrój } \\
\text { (Szczawno-Zdrój) }\end{array}$ & $\begin{array}{l}\text { park Zdrojowy, } \\
\text { nieopodal pomnika } \\
\text { H. Wieniawskiego }\end{array}$ \\
\hline $\begin{array}{c}\text { Cyprysik nutkajski } \\
\text { Xanthocyparsis } \\
\text { nootkatensis (D. Don) }\end{array}$ & 162 & $\begin{array}{l}\text { Sobótka } \\
\text { (Sobótka) }\end{array}$ & ul. Zamkowa \\
\hline $\begin{array}{c}\text { Jarząb brzęk } \\
\text { Sorbus torminalis (L.) } \\
\text { Crantz }\end{array}$ & 92 & $\begin{array}{c}\text { Wrocław } \\
\text { (Miasto Wrocław) }\end{array}$ & park Szczytnicki \\
\hline $\begin{array}{c}\text { Orzesznik } \\
\text { siedmiolistkowy } \\
\text { Carya laciniosa (F. Michx.) } \\
\text { G. Don }\end{array}$ & 237 & $\begin{array}{c}\text { Lubań } \\
\text { (Miasto Lubań) }\end{array}$ & park miejski \\
\hline $\begin{array}{l}\text { Klon jawor 'Leopoldii' } \\
\text { Acer pseudoplatanus L. } \\
\text { 'Leopoldii' }\end{array}$ & 302 & $\begin{array}{l}\text { Szczawno-Zdrój } \\
\text { (Szczawno-Zdrój) }\end{array}$ & $\begin{array}{c}\text { skrzyżowanie } \\
\text { ul. Wojska Polskiego } \\
\text { i ul. Ogrodowej, } \\
\text { w pobliżu pijalni wód }\end{array}$ \\
\hline
\end{tabular}


Tabela 1 (cd.)

\begin{tabular}{|c|c|c|c|}
\hline $\begin{array}{c}\text { Nazwa gatunkowa } \\
\text { polska i łacińska }\end{array}$ & $\begin{array}{c}\text { Obwód } \\
{[\mathrm{cm}]}\end{array}$ & $\begin{array}{c}\text { Miejscowość } \\
\text { (gmina) }\end{array}$ & Lokalizacja \\
\hline $\begin{array}{c}\text { Jodła olbrzymia } \\
\text { Abies grandis (Douglas } \\
\text { ex D. Don) Lindl. }\end{array}$ & 300 & $\begin{array}{c}\text { Szczawno-Zdrój } \\
\text { (Szczawno-Zdrój) }\end{array}$ & $\begin{array}{c}\text { park Zdrojowy, } \\
\text { nolanie za pomnikiem } \\
\text { H. Wieniawskiego }\end{array}$ \\
\hline $\begin{array}{c}\text { Sosna żółta } \\
\text { Pinus ponderosa Dougl. ex } \\
\text { C. Lawson }\end{array}$ & 236 & $\begin{array}{c}\text { Szczawno-Zdrój } \\
\text { (Szczawno-Zdrój) }\end{array}$ & $\begin{array}{c}\text { park Szwedzki, } \\
\text { na brzegu polany } \\
\text { parkowej, } \\
\text { przy większym stawie }\end{array}$ \\
\hline $\begin{array}{c}\text { Orzech czarny } \\
\text { Juglans nigra L. }\end{array}$ & 256 & $\begin{array}{c}\text { Legnica } \\
\text { (Miasto Legnica) }\end{array}$ & $\begin{array}{c}\text { ul. Chojnowska 81, } \\
\text { przy budynku szpitala }\end{array}$ \\
\hline $\begin{array}{c}\text { Lipa Maksymowicza } \\
\text { Tilia maximowicziana } \\
\text { Shiras. }\end{array}$ & 300 & $\begin{array}{c}\text { Wrocław } \\
\text { (Miasto Wrocław) }\end{array}$ & $\begin{array}{c}\text { park Brochowski, } \\
\text { przy głównej } \\
\text { alei parkowej }\end{array}$ \\
\hline $\begin{array}{c}\text { Klon czerwony } \\
\text { Acer rubrum L. }\end{array}$ & 300 & $\begin{array}{c}\text { Modła } \\
\text { (Gromadka) }\end{array}$ & park, przy kościele \\
\hline \multicolumn{2}{|c|}{} \\
\hline \multicolumn{2}{|c|}{} \\
\hline \multicolumn{2}{|c|}{}
\end{tabular}

Źródło: opracowanie własne na podstawie danych z RDOŚ we Wrocławiu.

Rzadkie i cenne drzewa sporadycznie obejmowane są ochroną pomnikową. Wśród unikatowych gatunków spotykanych na terenach zieleni historycznej Dolnego Śląska, które nie zostały ustanowione pomnikami przyrody, warto wskazać takie okazy, jak: klon kapadocki (Acer cappadocicum Gled.) - w parku Młodzieżowym w Świdnicy; perełkowiec japoński (Styphnolobium japonicum (L.) Schott) - w parku w Mściwojowie; kasztanowiec japoński (Aesculus turbinata Blume) - w parku Południowym we Wrocławiu; kłęk amerykański (Gymnocladus dioica (L.) K. Koch) - w parku miejskim w Żarowie i w parku przypałacowym w Mańczycach; fontanezja (Fontanesia phillyreoides Labill.) - na terenie Uniwersytetu Medycznego im. Piastów Śląskich we Wrocławiu; grusza wierzbolistna 'Pendula' (Pyrus salicifolia Pall.'Pendula'), w dawnym ogrodzie przy willi W. Hessego w Lubawce itp. Same parki wrocławskie, jak park Szczytnicki czy Południowy, mają charakter kolekcjonerski, gdzie w jednym miejscu występuje wiele rzadkich taksonów drzew i krzewów. Bogatą i różnorodną dendroflorą charakteryzują się również inne parki Dolnego Śląska, m.in. założenia parkowo-ogrodowe zlokalizowane na terenie Kotliny Jeleniogórskiej (Malicki, 2005, 2006, 2007, 2009). Drzewa te często wprowadzane były przez wybitnych architektów krajobrazu, jak P.J. Lenné czy E. Petzold, a później ich uczniów, działających niegdyś na tych terenach (Jaworek, 2014; Jaworek-Jakubska, 2019). Przez lata 
uważano, że gatunków introdukowanych nie należy uznawać za pomniki przyrody, dlatego nie przykładano większej wagi do obejmowania ich ochroną (Kasprzak, 2011). Niemniej jednak unikatowe są również stare drzewa odmian zarówno rodzimego, jak i obcego pochodzenia (rys. 1). Przykładowo w Bolkowie (powiat jaworski, gmina Bolków) rośnie jedyny udokumentowany na Dolnym Śląsku okaz kasztanowca pospolitego 'Laciniata' (Aesculus hippocastanum L. 'Laciniata'); w 2016 r. jego obwód wynosił $188 \mathrm{~cm}$ (Sobolewski, Ostrowska-Dudys, Janas, 2017). Należy nadmienić, że drzewo to 30 czerwca 2020 r. zostało uznane za pomnik przyrody. Odmiana ta występowała ponadto w Zarszynie (województwo podkarpackie) oraz w parku w Puławach (województwo lubelskie). Wprawdzie wspomniał o nich Seneta (1991), jednak okazy te nie dotrwały do współczesnych czasów. Niektóre gatunki czy odmiany są na tyle rzadkie, że spotkanie choćby dwóch egzemplarzy jest bardzo trudne. Przykładem może być odnalezienie zapomnianej już odmiany wiązu 'Pendula Wentwothii' przy pałacu Holyrood w Edynburgu, choć przedtem myślano, że przepadła bezpowrotnie (Science alert, 2016). We Wrocławiu w parku Szczytnickim do 2015 r. rósł dąb szypułkowy 'Heterophylla' (Quercus robur L. 'Heterophylla'); do tej pory nie odnotowano tej odmiany w wykazach powstałych po $2000 \mathrm{r}$. W Bolkowie natomiast zimą 2017 r. wycięto jesion pospolity 'Pendula Wentworthii' (Fraxinus excelsior L. 'Pendula Wentworthii'). Odmiana ta wspominana była przez McArdle i Santamoura (1984) w wykazie odmian jesionu wyniosłego, a wcześniejsze doniesienia z terenów Polski pochodzą wyłącznie od Senety (1996), który oznaczył to drzewo w Podzamczu. Odmiany osiągają często mniejsze wymiary obwodów niż gatunki typowe, dlatego też o tym, czy dane egzemplarze będą objęte ochroną pomnikową, powinna decydować ich wyjątkowość w skali regionu, a nie kryterium obwodu.

Zasoby cennych drzew z roku na rok ulegają uszczupleniu. Tak oto 24 listopada 2016 r. (Uchwała, 2016) zdjęto ochronę z jesionu wąskolistnego (Fraxinus angustifolia Vahl.), który rósł w Ziębicach (powiat ząbkowicki) - do tej pory jedynego przedstawiciela tego gatunku będącego pomnikiem przyrody. Zbiegło się to z utratą dwóch z trzech znanych i wymienionych w Leksykonie Zieleni Wrocławia jesionów wąskolistnych z Wrocławia, rosnących w parku Leśnickim oraz w parku przy dawnym klasztorze i liceum żeńskim Sióstr Urszulanek (Bińkowska, Szopińska, Matkowska, 2013). Z uwagi na zły stan zdrowia 28 marca 2019 r. (Uchwała, 2019) ochronę pomnikową zdjęto również z magnolii drzewiastej (Magnolia acuminata (L.) L.) o obwodzie $355 \mathrm{~cm}$, rosnącej w Krakowianach (gmina Długołęka), która jest reliktem nieistniejącego już parku (drzewo obecnie zamiera). 
Magnolia ta, wspominana przez Czekalskiego, Danielewicza, Kicińskiego i Aniśkę (2018), była drugim w kolejności największym udokumentowanym drzewem tego gatunku na Dolnym Śląsku, pod tym względem ustępowała jedynie magnolii drzewiastej z Głogowa, o obwodzie $513 \mathrm{~cm}$, która nie przetrwała wichury wiosną $2007 \mathrm{r}$.

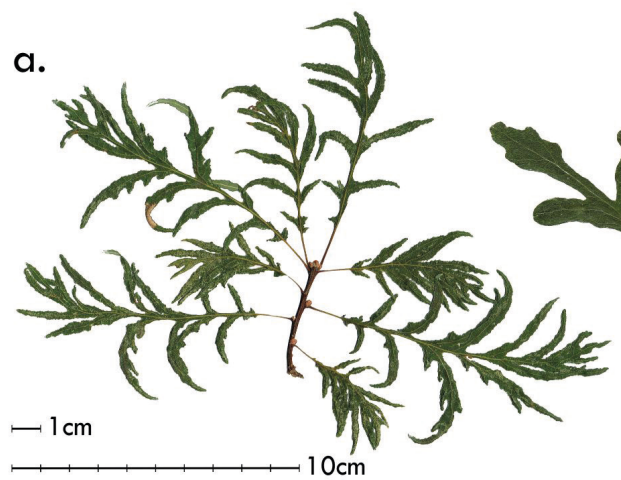

b.
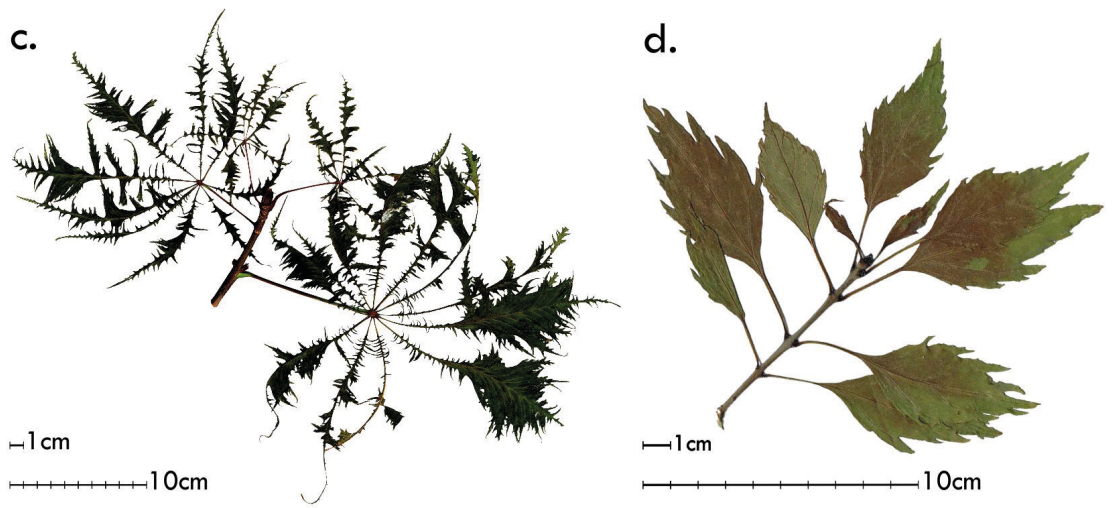

Rysunek 1 . Wybrane rzadkie odmiany drzew parkowych

o nietypowych blaszkach liściowych, spotykane na terenach historycznych:

a) dąb szypułkowy (Quercus robur L.) ‘Pectinata’, Wzgórze Kościuszki, Jelenia Góra;

b) dąb szypułkowy (Quercus robur L.) 'Heterophylla', park Szczytnicki Wrocław, drzewo rosło do 2015r.; c) kasztanowiec pospolity (Aesculus hippocastanum L.) 'Laciniata', ul. Ks. Bolka I, Bolków; d) jesion wąskolistny (Fraxinus angustifolia Vahl.) 'Monophylla Laciniata', park Południowy, Wrocław Źródło: zbiory R. Sobolewskiego

Drzewa cenne z uwagi na swoją wartość historyczną na terenach zurbanizowanych można podzielić na dwie grupy - rosnące w parkach oraz poza nimi. Ponadto same tereny należy podzielić na dwie kategorie - te, które pełnią funkcję zgodną z historyczną oraz odmienną od niej. Dotyczy to m.in. starych cmentarzy, które obecnie kojarzą się z rekreacją jak 
np. w parku Grabiszyńskim i parku Zachodnim we Wrocławiu (Bińkowska, Szopińska, Matkowska, 2013). W innych przypadkach wyłącznie pojedyncze drzewa stanowią pozostałość dawnych założeń ogrodowych, które całkowicie zatraciły swoje pierwotne znaczenie (fot. 3 i 4). Przykładem jest zlokalizowany w Bolkowie, niezachowany ogród dydaktyczny przy dawnej szkole wyższej dla chłopców i dziewcząt (niem. Höhere Knaben- und Mädchenschule), o którym przypominają wyłącznie stare okazy cennych drzew (Sobolewski, Ostrowska-Dudys, Janas, 2017).

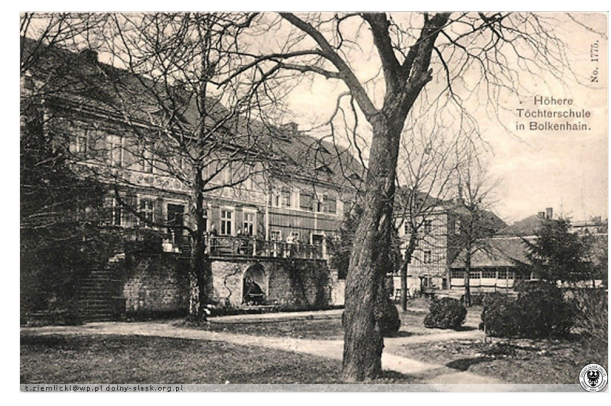

Fotografia 3. Dawny ogród dydaktyczny przy byłej szkole wyższej dla chłopców i dziewcząt w Bolkowie; na zdjęciu rosnący do dziś platan klonolistny - $1903 \mathrm{r}$. Źródło: Polska-org.pl (2019)

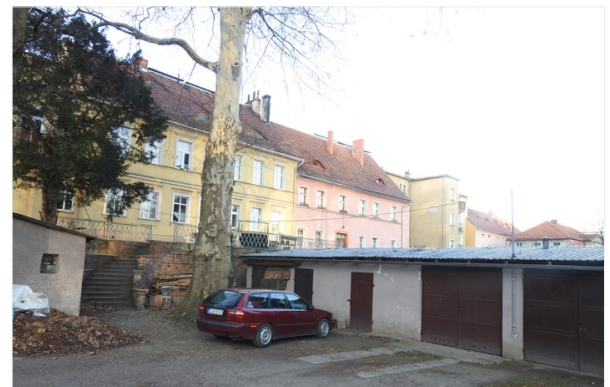

Fotografia 4. Dawny ogród dydaktyczny przy byłej szkole wyższej dla chłopców i dziewcząt w Bolkowie; na zdjęciu ponad 120-letni platan klonolistny - $2019 \mathrm{r}$. Źródło: M. Janas

W przypadku parków o niezmiennej funkcji można dokonać podziału na założenia o kompozycji zachowanej bądź zmienionej (częściowo zachowanej) w wyniku jej stopniowego zacierania. Wzorcowym przykładem założenia o zmienionej kompozycji jest park miejski w Żarowie (gmina Żarów). Na archiwalnych fotografiach widać grupę cypryśników błotnych (Taxodium distichum (L.) Rich.), rosnących na wyspie pośrodku nieistniejącego już stawu (fot. 5 i 6), podlegających ochronie pomnikowej od 2003 r. Drzewa te są reliktami niezachowanego układu wodnego (przez co wzrasta ich wartość historyczna i krajoznawcza), a co za tym idzie - pozostają jedynym z charakterystycznych elementów zabytkowego założenia.

Drzewa zawsze były elementem towarzyszącym nawet najmniejszym obiektom architektury, czego przykładem jest mała architektura sakralna (Cała, 2007; Tóth i in., 2019). Na Dolnym Śląsku, w miejscowościach podwrocławskich, można spotkać liczne obeliski, pomniki pamięci ofiar I wojny światowej (fot. 7 i 8). W takich miejscach często sadzono dęby szypułkowe (Quercus robur L.), czego przykładem są drzewa w takich 


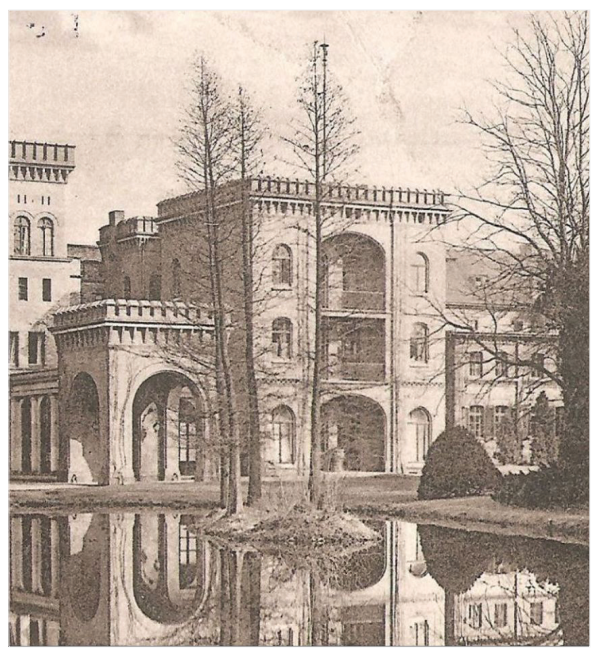

Fotografia 5. Grupa cypryśników błotnych (Taxodium distichum (L.) Rich) w parku Miejskim w Żarowie, relikt nieistniejącego zbiornika wodnego - $1910 \mathrm{r}$. Źródło: Polska-org.pl (2019)

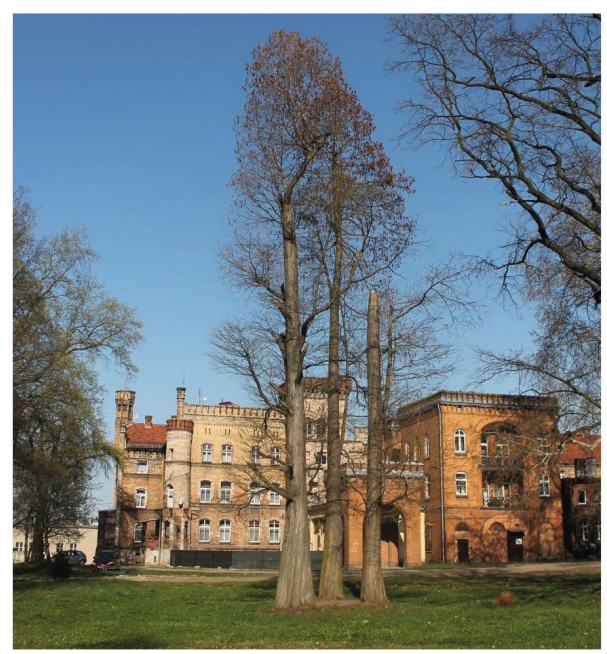

Fotografia 6. Grupa cypryśników błotnych (Taxodium distichum (L.) Rich) w parku Miejskim w Żarowie, relikt nieistniejącego zbiornika wodnego - $2019 \mathrm{r}$. Źródło: R. Sobolewski

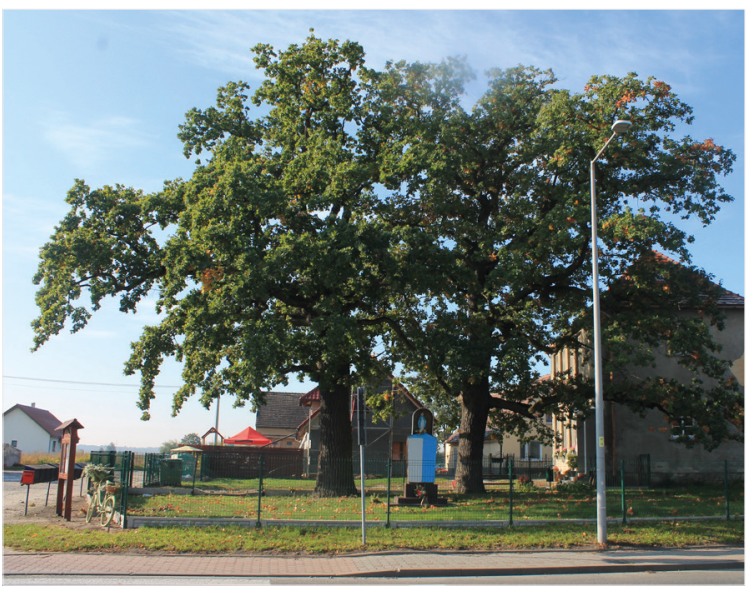

Fotografia 7. Dęby szypułkowe

(Quercus robur L.) przy pomniku pamięci ofiar I wojny światowej - Gać, gmina Oława Źródło: R. Sobolewski

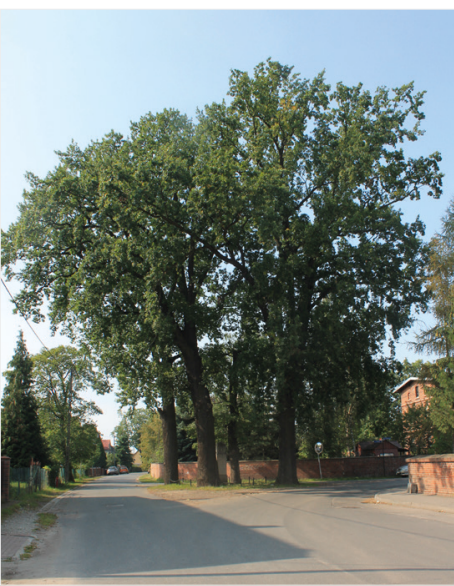

Fotografia 8. Dęby szypułkowe (Quercus robur L.) przy pomniku pamięci ofiar I wojny światowej - Gajków, gmina Czernica Źródło: R. Sobolewski 
miejscowościach, jak: Gajków (gmina Czernica), Gać (gmina Oława), Dziuplina (gmina Jelcz-Laskowice), Brzezia Łąka (gmina Długołęka). Rzadziej nasadzano lipy (Tilia L.) rodzime - jak w przypadku Łan (gmina Czernica) - które zinwentaryzowano w ramach projektu „Drzewa Dobrej Widawy". Drzewa rosnące w pobliżu monumentów często mają wymiary pomnikowe bądź zbliżone do nich. Warto wspomnieć, że same obeliski w niektórych miejscowościach, np. w Brzeziej Łące lub w Gaci, były likwidowane, a w miejscu, w którym się znajdowały, umieszczano podobizny Matki Boskiej bądź krzyże.

Wiele gatunków obcego pochodzenia szczególnie dobrze zaaklimatyzowało się w naszym kraju i stanowi obecnie trwały składnik krajobrazu, m.in. kasztanowiec pospolity (Aesculus hippocastanum L.), który przez wielu mieszkańców miast uznawany jest za gatunek rodzimy, czy platan klonolistny (Platanus $\times$ acerifolia (A.) Willd), który często kojarzony jest z Wrocławiem, ponieważ ponad 13\% okazów tego gatunku będących pomnikami przyrody na Dolnym Śląsku rośnie właśnie w tym mieście. Innym przykładem są coraz rzadziej spotykane aleje z głogu pośredniego 'Paul's Scarlet' (Crataegus × media Sarg. 'Paul's Scarlet'), którym obsadzone były liczne ulice na Dolnym Śląsku. O tym, że ta odmiana była doceniana nie tylko na tym terenie, możemy przeczytać we wspomnieniach Przybory (2016), pt. Przymknięte oko Opaczności. Memuarów części wszystkie, w których pisał, że kwitnące na czerwono i różowo głogi były dla niego symbolem Bydgoszczy.

Ochrona drzew ma szczególny wymiar dla krajoznawstwa z uwagi na ich wartość krajobrazową. Choć często jest ona utożsamiana z ozdobą, należy ją rozumieć jako powiązanie drzew z innymi elementami przestrzeni (krajobrazu). Przykładem mogą być drzewa tworzące ramy osi widokowej lub grupa drzew zmieniająca swoją plastyczność w trakcie roku kalendarzowego. Natomiast wartość ozdobna należy do cech gatunkowych i indywidualnych, jak kwiaty, owoce czy pokrój.

Wartym rozpatrzenia sposobem nadania rangi drzewom jest kategoryzacja pomników przyrody, zaproponowana przez Zarzyńskiego i Grzywacza (2019), jednak powinna ona obejmować również klasyfikację regionalną opracowaną na podstawie cech i historii regionu, a nie tylko kraju czy Unii Europejskiej. Pietrzak-Zawadka (2016) proponuje podział pomników przyrody na trzy klasy - pod kątem ich wartości społecznej i przyrodniczej, nawiązując również do ich wartości turystycznej i kulturowej. Drzewa o małej wartości (klasa III) to według autorki takie, które rosną na terenach trudno dostępnych, są nieznane okolicznym 
mieszkańcom, nie posiadają nazwy własnej, rosną na dużym obszarze zadrzewionym, brak na ich temat legend i podań; lub drzewa mające obwód mniejszy od minimalnego obwodu dla pomników przyrody. Kryteria przejęte przez autorkę mogą być dyskusyjne, umniejszające wartość drzew w dość niezrozumiały sposób. Choć można uznać, że niektóry kategorie mają aspekt praktyczny, np. drzewa rosnące na terenach o ograniczonej dostępności (tj. tereny prywatne) trudniej wcielić $\mathrm{w}$ infrastrukturę turystyczna, to sama dostępność czy brak nazwy własnej wcale nie umniejszają ich wartości. Nazwa własna jest istotna głównie w kontekście społecznym - drzewo, które ją ma, staje się mniej anonimowe; zaczynamy się z nim identyfikować. Z uwagi na swoją rolę nazwa powinna mieć wymiar historyczny, związany z przeszłością miejsca, wybitnymi postaciami zasłużonymi dla regionu, do czego nawiązuje również Pietrzak-Zawadka (2016).

Rolą krajoznawstwa jest szerzenie wiedzy o regionie, również o drzewach mniej znanych okolicznym mieszkańcom, w powiązaniu z dziedzinami nauk przyrodniczych. W konsekwencji działalność ta może przyczynić się do zainicjowania więzi społecznych pomiędzy drzewem a lokalną społecznością. W przypadku okazów średniej wartości (klasy II i III) Pietrzak-Zawadka (2016) podaje, że drzewo powinno rosnąć na szlaku turystycznym bądź na ścieżce edukacyjnej. Same ścieżki i szlaki turystyczne to produkty powstałe w konsekwencji nagromadzania się obiektów wartych uwagi, tak więc obecność drzewa determinuje ich utworzenie, a nie na odwrót. Na tej podstawie spośród okazów istotnych dla krajoznawstwa można wyodrębnić egzemplarze ważne dla turystyki. W krajoznawstwie znaczenie ma każde drzewo w powiązaniu $\mathrm{z}$ historią miejsca i krajobrazu, natomiast w przypadku turystyki istotne są wybrane okazy, których selekcja wynika z pewnych ograniczeń, np. z wcześniej wymienionej dostępności. Dla przykładu w Lubawce (powiat kamiennogórski), na terenie dawnej willi właściciela fabryki mebli W. Hessego, rośnie grusza wierzbolistna 'Pendula' o obwodzie $99 \mathrm{~cm}$ (dane z 2013 r.), której wiek szacowany jest na mniej więcej 100 lat. Uznaje się ją za unikat w skali regionu, a nawet województwa dolnośląskiego. Grusza ta rośnie na terenie prywatnym, niedostępnym dla przeciętnego turysty, co utrudnia wykorzystanie jej w promocji miasta.

Przykład Bolkowa pokazuje, że powstanie ścieżki edukacyjnej może mieć pozytywny wpływ na poszerzenie wiedzy o regionie, a zieleń przestaje być anonimowa (rys. 2). Samo utworzenie ścieżki dendrologicznej na podstawie występowania najcenniejszych drzew w mieście miało na celu: 
- dbanie o to, by mieszkańcy miasta i przybywający do niego turyści mieli świadomość przyrodniczą na temat osobliwych i rzadkich drzew rosnących w granicach miasta;

- ochronę najcenniejszych egzemplarzy dendroflory miasta;

- uwzględnienie zieleni jako elementu turystycznego dopełniającego części historyczne Bolkowa i przekierowanie ruchu turystycznego do centrum miasta.

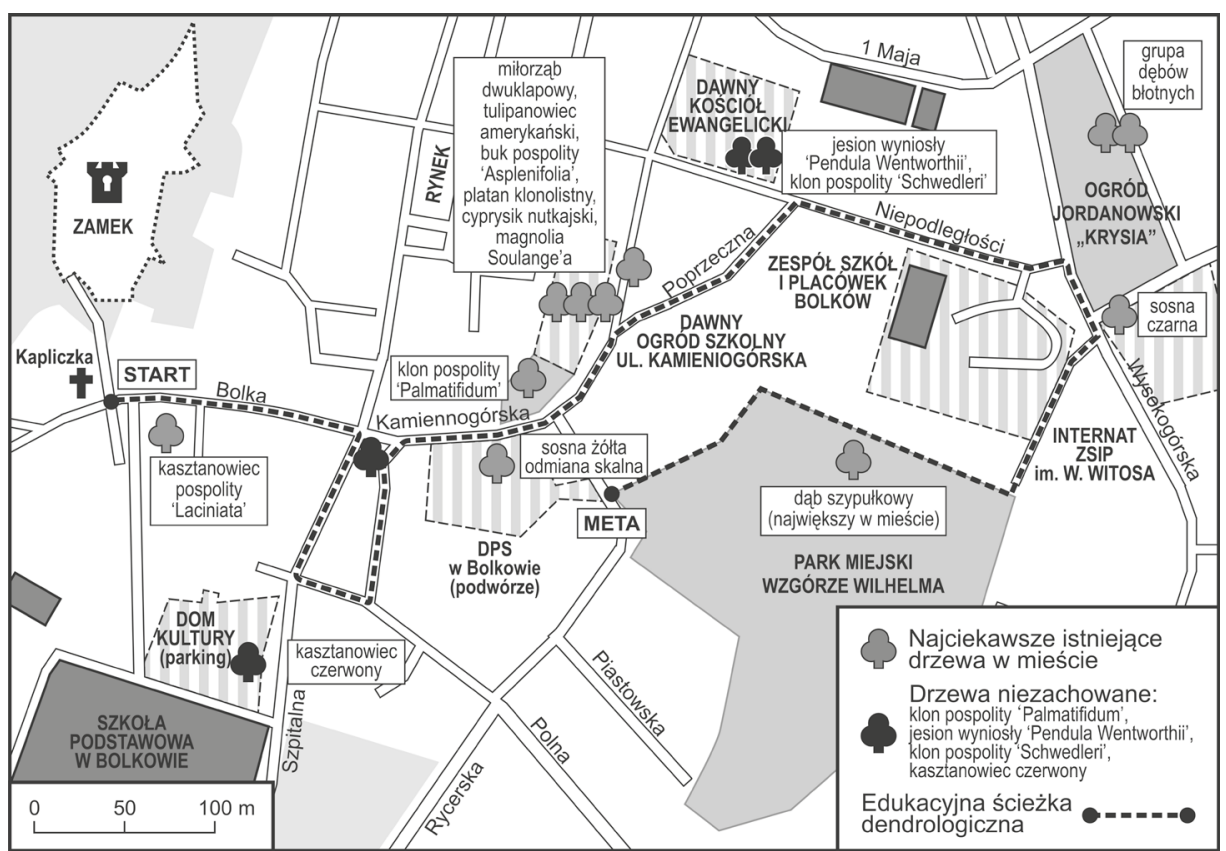

Rysunek 2. Trasa ścieżki dendrologicznej w Bolkowie, stan na styczeń 2019 r. Źródło: opracowanie własne na podstawie Starostwo Powiatowe w Jaworze (2019)

Atrakcyjność ścieżki jest uzależniona od zróżnicowania dendroflory danego obszaru. W przypadku Bolkowa najcenniejsze drzewa znajdowały się głównie poza parkami, co umożliwiło poprowadzenie szlaku przez całe miasto. Ponadto ścieżka powinna mieć charakter rozwojowy, a więc warto rozszerzać ją o sąsiednie miejscowości, szukać powiązań z historią miejsc występowania określonych drzew, porównywać do zasobów całego regionu. Na terenie gminy Bolków w kolejnych latach po otworzeniu ścieżki odnaleziono m.in. lipę srebrzystą (Tilia tomentosa Moench) w Wierzchosławicach, ale trzeba również zaznaczyć, że od tego czasu część drzew zniknęła trwale z krajobrazu miasta. Natomiast podczas prac związanych $z$ opracowywaniem trasy na jednej z fotografii 
udało się zidentyfikować niezachowany już okaz klonu pospolitego 'Palmatifidum' (Acer platanoides L. 'Palmatifidum'), którego stare okazy występują jeszcze w kilku miejscach na Dolnym Śląsku, m.in. we Wrocławiu i Żarowie. Zarzycki, Flocik, Woźnicka, Gancarek i Lewandowaska (2015) wymieniają wiele zalet flory jako elementu ekoturyzmu na przykładzie województwa śląskiego, do których należą zarówno łatwość obserwacji i fotografowania, jak i zróżnicowanie flory w województwie, co odnosić się może także do drzew o wybitnej wartości przyrodniczej, historycznej, kulturowej, społecznej i krajobrazowej.

W przypadku projektu „Drzewa Dobrej Widawy”, realizowanego przez Fundację Aquila, zaproponowane szlaki turystyczne wytyczane były przez kolejne miejscowości w trzech gminach. Wyznaczając trasę, brano pod uwagę: różnorodność gatunkową drzew (za najciekawsze uznano obszary zróżnicowane gatunkowo); obecność okazów, których obwody przekraczają średnią wartość dla drzew pomnikowych rosnących na Dolnym Śląsku; występowanie drzew unikatowych; drzewa towarzyszące ważnym obiektom historycznym; obecność alei, cmentarzy i parków. Najciekawsza pod tym względem okazała się gmina Długołęka, wyróżniająca się bardzo dużymi zasobami zróżnicowanej zieleni. Warte uwagi jest to, że w Godzieszowej (gmina Długołęka), na cześć rosnących tam dwóch tulipanowców amerykańskich (Liriodendron tulipifera L.) ustanowiono Święto Tulipanowca, co świadczy o przywiązaniu mieszkańców do tych okazów i historii, mimo że same drzewa nie mają statusu pomnika przyrody. Podobne święto na cześć tego gatunku obchodzi się w Sichowie (gmina Męcinka). Znajdujący się tam okaz jest największym ustanowionym pomnikiem przyrody tego gatunku na Dolnym Śląsku. W roku ustanowienia obwód tego drzewa wynosił $470 \mathrm{~cm}$.

Krajoznawstwem pośrednio zajmują się tree hunterzy, jak P. Lenart (2019) czy M. Łuszczyński (2019), którzy poprzez swoją pasję i działalność popularyzują oraz przybliżają najciekawsze drzewa Polski, niekoniecznie będące pomnikami przyrody. Również coraz więcej organizacji i fundacji widzi potrzebę ochrony zieleni w kontekście zachowania dziedzictwa historycznego regionu, jak w przypadku Fundacji Inicjatywy B, która przeznacza własne środki, by chronić, m.in. ważny dla tożsamości regionalnej park Miejski w Żarowie.

Krajoznawstwo ma na celu szerzenie wiedzy o regionie, a także promowanie cennych, choć mniej znanych drzew. W przyszłości może się to przyczynić do ich rozpoznawalności w regionie, a nawet kraju. W wielu miastach, m.in. we Wrocławiu, Szczecinie, Warszawie i Łodzi, coraz popularniejsze stają się tematyczne spacery dendrologiczne, ponieważ są 
one atrakcyjne dla różnych grup wiekowych, niezależnie od pory roku. Co ciekawe, bardzo dużym zainteresowaniem cieszą się spacery zimowe, urządzane w celu oglądania dendroflory w stanie bezlistnym. Dzięki temu ludzie mogą poznać różnorodność dendroflory miast, w których żyją. Wpływa to na kształtowanie świadomości i wrażliwości przyrodniczej oraz pogłębianie wiedzy o tożsamości regionu.

\section{Wnioski}

Ważnym elementem krajoznawstwa są nie tylko pomniki przyrody, ale wszystkie drzewa o udokumentowanej wartości historycznej, kulturowej, przyrodniczej, społecznej i krajobrazowej. Wiedza na temat dendroflory regionu pozwala spojrzeć na krajoznawstwo przez pryzmat jego interdyscyplinarności. Ochrona zieleni jest jednoznaczna z działaniami na rzecz dbania o tożsamość regionu. Szczegółowa wiedza na temat dendroflory regionu pomaga zarówno w ochronie, jak i w wykorzystaniu jej potencjału, np. w celach turystycznych i promocyjnych gmin, a także integracji lokalnej społeczności.

\section{Bibliografia}

Affek-Starczewska, A., Starczewski, K., Pawlonka, Z., Skrzyczyńska, J. (2014). Drzewa - pomniki przyrody jako element krajobrazu kulturowego. Studia Ecologiae et Bioethicae, 12 (3), 55-63.

Bińkowska, I., Szopińska, E., Matkowska, A.H. (red.) (2013). Leksykon Zieleni Wroctawia. Wrocław: Wydawnictwo Via Nova.

Cała, A. (2007). Krajobraz z sacrum w tle - kapliczki przydrożne jako element krajobrazu wsi opolskich. Teka Komisji Architektury, Urbanistyki i Studiów. Krajobrazowych, 3, 24-34.

Czekalski, M., Danielewicz, W., Kiciński, P., Aniśko, T. (2018). Magnolia drzewiasta (Magnolia acuminata (L.) L.) w Polsce. Rocznik Polskiego Towarzystwa Dendrologicznego, $66,85-95$.

Fortuna-Antoszkiewicz, B., Łukaszkiewicz, J., (2018). Zabytkowy zespół alej w Radziejowicach - kulturowe dziedzictwo Mazowsza. Ocena stanu zachowania i wartości obiektu. Mazowsze. Studia Regionalne, 24, 63-83.

Gębska, K., Jakubska, A. (2007). Dendroflora parku miejskiego w Ziębicach. Przyroda Sudetów, 10, 77-84.

Grzywacz, A. (2011). Drzewa w krajobrazie kulturowym. Zarządzanie Ochrona Przyrody w Lasach, 5, 245-259.

Jaworek, J. (2014). The principles of plant selection in gardens designed by Eduard Petzold (1815-1891). Czasopismo Techniczne, 11 (6), 225-238. 
Jaworek-Jakubska, J. (2019). "As masterly as very few others are..." - the polish gardens of Peter Joseph Lenné. An example of Polish-German study into the history and maintenance of historical garden. Czasopismo Techniczne, 10, 5-20.

Kasprzak, K. (2011). Drzewa - pomniki przyrody i pamiątki kultury. Turystyka Kulturowa, 4, 17-38.

Lenart, P. (2019). Pobrano z: www.pawellenart.pl (20.12.2019).

Łuszczyński, M. (2019). Pobrano z: www.pomniki-przyrody.odskok.pl (20.12.2019).

Malicki, M. (2005). Drzewa i krzewy parku przypałacowego w Maciejowcu. Rocznik Dendrologiczny, 53, 127-134.

Malicki, M. (2006). Dendroflora parku miejskiego na Wzgórzu Kościuszki w Jeleniej Górze. Przyroda Sudetów, 9, 61-70.

Malicki, M. (2007). Dendroflora parku przy pałacu myśliwskim w Karpnikach. Przyroda Sudetów, 10, 63-76.

Malicki, M. (2009). Notatki dendrologiczne z Sudetów, część I. Parki przypałacowe w Łomnicy, Ostróżnie, Studniskach Dolnych i Włosieniu (Pogórze Izerskie). Przyroda Sudetów, 12, 51-65.

Markulak, D. (2014). Pomniki przyrody gminy Gubin i Brody. Zeszyty Naukowe. Inżynieria Środowiska, 153 (33), 56-66.

McArdle, A.J., Santamour, F.S. Jr. (1984). Checklists of cultivars of European ash (Fraxinus) species. J. Arboric., 10 (1), 21-32.

Orłowski, G., Nowak, L. (2007). The importance of marginal habitats for the conservation of old trees in agricultural landscapes. Landscape Urban Plan, 79, 77-83.

Pietrzak-Zawadka, J. (2015). Kryteria wymiarowe uznawania drzew za pomniki przyrody w Polsce. Sylwan, 159 (3), 227-235.

Pietrzak-Zawadka, J. (2016). Przyrodnicze i społeczne kryteria uznawania drzew za pomniki przyrody. Sylwan, 160 (2), 162-168.

Polska-org.pl (2019). Pobrane z: https://polska-org.pl (30.11.2019).

Przybora, J. (2016). Przymknięte oko Opaczności. Memuarów części wszystkie. Kraków: Znak.

Science alert (2016). Pobrane z: www.sciencealert.com/2-trees-presumed-extinct-for-half-a-century-have-just-been-discovered-in-the-queen-s-garden (20.12.2019).

Seneta, W. (1991). Drzewa i krzewy liściaste. T. I: A-B. Warszawa: Państwowe Wydawnictwo Naukowe.

Seneta, W. (1996). Drzewa i krzewy liściaste. T. III: D-H. Warszawa: Państwowe Wydawnictwo Naukowe.

Sobolewski, R.K., Ostrowska-Dudys, M.B., Janas, M.J. (2017). Wartość przyrodniczo-historyczna osobliwości dendrologicznych Bolkowa na Dolnym Śląsku. Nauka Przyroda Technologie, 11 (4), 343-354.

Sobolewski, R.K., Sabura-Mielnik, K.M., Szopińska, E.M. (2018). Pozyskiwanie danych o pomnikach przyrody - propozycja karty ewidencyjnej dla drzew pomnikowych. Część pierwsza. Acta Scientiarum Polonorum Formatio Circumiectus, 17 (1), 209-221.

Starostwo Powiatowe w Jaworze (2019). Pobrane z: https://jaworski.e-mapa.net/ (20.12.20219).

Szczepański, M.R., Wrońska-Pilarek, D., Janyszek, M. (2018). Dendroflora zabytkowego parku dworskiego w Małym Buczku w województwie wielkopolskim. Nauka Przyroda Technologie, 2 (12), 185-197.

Szopińska, E., Reda, P. (2003). Notatki dendrologiczne z parków Wrocławia. Cz. 1. Park Szczytnicki. Rocznik Dendrologiczny, 51, 159-170. 
Tóth, A., Timpe, A., Stiles, R., Damyanovic, D., Valánszki, I., Salašová, A., Cieszewska, A., Brabec, E. (2019). Small sacral Christian architecture in the cultural landscapes of Europe. Acta Horticulture et Regiotecturae, 22 (1), 1-7.

Uchwała nr 183/VII/2016 Rady Miejskiej w Ziębicach z dnia 24 listopada 2016 r. w sprawie zniesienia formy ochrony przyrody dwóch drzew uznanych za pomniki przyrody.

Uchwała nr VI/57/19 Rady Gminy Długołęa z dnia 21 marca 2019 r. w sprawie zniesienia formy ochrony drzewa uznanego za pomnik przyrody.

Zarzycki, W., Flocik, Ł., Woźnicka, P., Garncarek, M., Lewandowska, A. (2015). Gatunki charakterystyczne $\mathrm{i}$ ich potencjał $\mathrm{w}$ rozwoju ekoturystyki na przykładzie województwa śląskiego. W: E. Szczęśniak, W. Drzewiecki (red.), Srodowisko Śląska oczami przyrodników (s. 5-15). Wrocław: [b.w.].

Zarzyński, P., Grzywacz, A. (2019). Kategoryzacja drzew jako pomników przyrody na podstawie ich walorów przyrodniczych, historycznych i społecznych. Sylwan, 163 (4), 338-347.

\title{
Podziękowania
}

Autor serdeczne podziękowania kieruje do Towarzystwa Miłośników Bolkowa, Fundacji Aquila i Fundacji Inicjatywy B za możliwość wzięcia udziału w projektach, bez których niniejszy artykuł by nie powstał. Dziękuje również Pani Joannie Lewandowskiej za zdjęcie sosny ze Szklarskiej Poręby oraz Panu Markowi Janasowi z Towarzystwa Miłośników Bolkowa za współczesną fotografię dawnego ogrodu dydaktycznego, a także Pani Kornelii Tęczy za wskazanie cytatu z książki Przymknięte oko Opaczności. Memuarów części wszystkie Jeremiego Przybory. Wyrazy wdzięczności przesyła Pani Anecie Kozakiewicz za dokonanie korekty językowej.

\section{ROLA DENDROFLORY WE WZBOGACANIU WALORÓW KRAJOZNAWCZYCH OBSZARÓW ZURBANIZOWANYCH}

\begin{abstract}
Abstrakt: Drzewa są ważnym elementem terenów zurbanizowanych, trwale wpisanym w historię i krajobraz wielu polskich miejscowości. Ich obecność mocno powiązana jest z działalnością człowieka i historią miejsca, w którym rosną. Niniejszy artykuł stanowi podsumowanie przeprowadzonych w latach 2016-2019 badań dotyczących wartości historycznej drzew. Celem opracowania jest określenie roli drzew w krajoznawstwie dla potrzeb ochrony tożsamości regionalnej i rozwoju turystyki na historycznie cennych obszarach zurbanizowanych Dolnego Śląska. Na analizowanym terenie można spotkać wiele wartościowych i unikatowych drzew, część z nich do tej pory nie jest objęta żadną formą ochrony. Ich wyjątkowość wiąże się nie tylko z osiąganymi rozmiarami, ale też ze znaczeniem kulturowym czy historycznym. Drzewa te często są pozostałością niezachowanych obiektów, dawnych parków czy ogrodów. Archiwalne fotografie umożliwiają nam ocenę wartości historycznej drzew, ich wieku, roli w krajobrazie. Ochrona zieleni, a zwłaszcza drzew, może wspomóc działania na rzecz podtrzymywania tożsamości regionu - jej potencjał może być wykorzystany np. do celów turystycznych i promocyjnych gmin, a także do integracji lokalnej społeczności.
\end{abstract}

Słowa kluczowe: pomnik przyrody, wartość historyczna drzew, zieleń historyczna, dziedzictwo kulturowe, drzewa w krajobrazie. 


\section{THE MEANING OF TREES IN URBAN AREAS AS A PART OF REGIONAL IDENTITY}

Abstract: Trees are an important element of urban areas closely related to the history and
landscapes of many Polish towns and cities. Their presence is strongly associated with
human activity and the history of the place where they grow. This work is a summary of
research on the historical values of trees carried out between 2016 and 2019 and its aim
is to determine the meaning of trees for the purposes of protecting regional identity and
to develop tourism in historically valuable urbanized areas of Lower Silesia. There are
many valuable and unique trees in Lower Silesia and some have yet to be protected. Their
uniqueness is associated not only with their size, but also with their cultural or historical
value. These trees are often related to historical sites such as parks or gardens which have
not been preserved. Archival photographs enable us to assess their historical value, their
age and role in the landscape. The protection of greenery, especially trees, can support
the protection of regional identity in order to use its potential, for instance for tourist
and promotional purposes in communes, as well as for integrating the local community.

Keywords: monumental tree, historical value of trees, historical greenery, cultural heritage, trees in the landscape. 